Research Article

\title{
Assessment of Landfill Odorous Gas Effect on Surrounding Environment
}

\author{
Si-liang Shen $\mathbb{D}$, Bin-hai Wu $\mathbb{D}$, Hui Xu $\mathbb{D}$, and Zhen-ying Zhang $\mathbb{D}$ \\ School of Civil Engineering and Architecture, Zhejiang Sci-Tech University, Hangzhou 310018, China \\ Correspondence should be addressed to Hui Xu; xuhui@zstu.edu.cn
}

Received 15 May 2020; Revised 6 August 2020; Accepted 7 September 2020; Published 23 September 2020

Academic Editor: Qiang Tang

Copyright (C) 2020 Si-liang Shen et al. This is an open access article distributed under the Creative Commons Attribution License, which permits unrestricted use, distribution, and reproduction in any medium, provided the original work is properly cited.

\begin{abstract}
Landfill odorous gas emission has been a serious environmental problem, especially for the residents or passersby on the road near the landfill. In this paper, in situ monitoring and the numerical CALPUFF model were adopted to analyze the odor nuisance problem caused by municipal solid waste (MSW) degradation in a large landfill. The static chamber technique was used to measure the odorous gas emission rate on the working area, temporary cover area, and final cover area of the landfill during Dec. 2016 and Apr. 2018. The results showed that the emission rate of $\mathrm{H}_{2} \mathrm{~S}$ on the working area varied from $0.003 \mathrm{mg} / \mathrm{m}^{2} / \mathrm{min}$ to $0.98 \mathrm{mg} / \mathrm{m}^{2} / \mathrm{min}$, and it was positively correlated with the ambient temperature. The emission of $\mathrm{H}_{2} \mathrm{~S}$ varied between $0.125 \mathrm{~kg} / \mathrm{h}$ and $1.09 \mathrm{~kg} / \mathrm{h}$ on the working area, and it varied between $9.2 \times 10^{-6} \mathrm{~kg} / \mathrm{h}$ and $6.8 \times 10^{-4} \mathrm{~kg} / \mathrm{h}$ on the temporary cover when considering the impact of the holes in a high-density polyethylene (HDPE) membrane, and it was negligible on the final cover. The contribution rates of $\mathrm{H}_{2} \mathrm{~S}$ emission in the whole landfill were $90.79 \% \sim 98.59 \%$ and $0.0008 \% \sim 0.52 \%$ for the working area and the temporary cover area, respectively. The numerical simulation showed that wind velocity and gas emission rates were the critical factors that affect odor dispersion. To limit the $\mathrm{H}_{2} \mathrm{~S}$-influenced area within the landfill site, proper engineering measures should be taken to ensure the $\mathrm{H}_{2} \mathrm{~S}$ emission rate of lower than $15 \%$ of its original value.
\end{abstract}

\section{Introduction}

With the increasing of urbanization, a large number of transportation infrastructures with tremendous traffic and human flow (e.g., highways and tunnels) appear around the municipal solid waste (MSW) landfill. The degradation of MSW would generate less than $1 \% \mathrm{v} / \mathrm{v}$ nonmethane compounds, which are considered to be one of the primary sources of odor emissions [1]. The formation of these odorous gases originated from the secondary product during the waste degradation or strip of the mixed materials existed in the MSW. Compared with the MSW in developed European and American countries, the kitchen waste accounts for $40 \% \sim 85 \%$ (wet basis) of the MSW in China, and the initial water content varies from $30 \%$ to $70 \%$ (wet basis) [2]. Thus, a greater variety of odorous gases could be measured around the landfill in China [3-5]. The health of the residents and passersby in and around the landfill site will be significantly influenced by the harmful odorous gases. The odor-related nuisance has become the major cause of complaints to the local authorities [6]. The high concentration of $\mathrm{H}_{2} \mathrm{~S}$ could be measured in all the landfills monitoring at home and abroad, ranging from $0.004 \mathrm{ppm}$ to $0.64 \mathrm{ppm}$ [7-9]. Besides, the olfactory threshold of $\mathrm{H}_{2} \mathrm{~S}$ is only $0.41 \mathrm{ppb}$, which caused the $\mathrm{H}_{2} \mathrm{~S}$ chosen as the representative odor gas of landfills [5].

The gas migration in the air directly related to the local meteorological conditions [10]. Some specific weather conditions, including low mixing height or low wind speed could severely affect the odor dispersion process. Landfills are often located in complex terrain areas. The meteorological conditions are challenging to predict, which leads to the complexity of odor prediction. To assess the individual's perception of the odorous material, the quantification of compounds concentration, which is perceived by receptors, could be the most effective way [11]. Capelli et al. indicated that dispersion models had become a valuable tool to evaluate odor pollution [12]. Some air dispersion models, such as AERMOD and CALPUFF, recommended by the National Standard (HJ2.2-2008) could analyze the gas 
migration in the range of tens of meters to tens of kilometers [13]. The existing research studies prefer to use the CALPUFF to assess the gas migration due to the limitations of the AERMOD model, including the incapability of handling the calm wind condition and steady-state assumption [14].

This paper mainly focused on the impact of the air pollution caused by the MSW degradation on the residents or passersby on the road near the landfill. In situ monitoring and the CALPUFF model were used to evaluate the long-term $\mathrm{H}_{2} \mathrm{~S}$ emission rate and the key factors which may affect the gas diffusion in the air. A proper method should be adopted to reduce the $\mathrm{H}_{2} \mathrm{~S}$ fugitive emission in the working area. The result could be used to improve landfill operations and management.

\section{Materials and Methods}

2.1. Site Description. The investigated MSW landfill is located in the northern part of Hangzhou City $\left(120^{\circ} 12^{\prime} \mathrm{E}\right.$, $\left.30^{\circ} 23^{\prime} \mathrm{N}\right)$. It is the first standardized valley-type sanitary landfill in China. The area of the landfill is $700,000 \mathrm{~m}^{2}$. It was designed to contain 22 million $\mathrm{m}^{3}$ of MSW. The site does not accept medical, industrial, and hazardous waste. The daily amount of landfilled MSW increased to $6655 \mathrm{t} / \mathrm{d}$ since 2017 [15].

The total surface area of the landfill is $438,000 \mathrm{~m}^{2}$ and comprises three parts: working area, temporary cover area, and final cover area. $1.5 \mathrm{~mm}$ thick high-density polyethylene (HDPE) was used as the only temporary cover material. Gas wells were installed to collect landfill gas (LFG) for electricity generation. The size of the working area is approximately $6000 \mathrm{~m}^{2}$. There are many municipal structures scattered around the landfill within a radius of $5 \mathrm{~km}$.

2.2. Gas Sampling and Analysis. As shown in Figure 1, sampling points were distributed on the landfill working area, temporary cover area, and final cover area. Twelve sampling points for each campaign were randomly arranged on the working area in each campaign following US EPA requirements. The monitoring above the temporary cover focused on the gas emission from the leakage point.

The static chamber and $10 \mathrm{ml}$ syringe were used to collect landfill gas from selected locations. The chamber used in this study consists of a glass cylinder and a steel pedestal. The chamber is $550 \mathrm{~mm}$ in height and $500 \mathrm{~mm}$ in diameter. Once the chamber was placed on the sampling location, the groove in the steel pedestal was filled with water to keep the chamber sealed. All the valves were then shut off to allow the gas to accumulate into the chamber. The gas was sampled for 1 hour every 4 hours. A 1-L empty aluminum bag was connected to the chamber to equilibrate inner pressure. The gas emission rate was determined by equations (1) and (2) [16]:

$$
\begin{aligned}
V C_{t+\Delta t} & =V C_{t}+j^{\prime} S \Delta t, \\
j^{\prime} & =\frac{V}{S} \frac{\Delta C}{\Delta t},
\end{aligned}
$$

where $V$ is the volume of the chamber $\left(\mathrm{m}^{3}\right) ; C$ is the $\mathrm{H}_{2} \mathrm{~S}$ concentration $\left(\mathrm{mg} / \mathrm{m}^{3}\right) ; S$ is the area of the chamber base $\left(\mathrm{m}^{2}\right) ; j^{\prime}$ is the gas flux $\left(\mathrm{mg} / \mathrm{m}^{2} / \mathrm{h}\right) ; t$ is the time (min); $\Delta C$ is the gas concentration difference between time $t$ and time $t+\Delta t$.

The sulfur-containing gas analysis was carried out by using a gas chromatograph with a flame photometric detector (FPD, HC-3, Hubei, China shafts Technology Co., Ltd.). FPD conditions were as follows: nitrogen was used as the carrier gas at the pressure of $0.1 \mathrm{MPa}$; the pressure of hydrogen and oxygen was adjusted to $0.04 \mathrm{MPa}$ to form a hydrogen-rich flame; the temperature of the column and detector was held at $125^{\circ} \mathrm{C}$ and $100^{\circ} \mathrm{C}$, respectively; $1 \mathrm{~mL}$ sample from anaerobic tubes was directly injected into the injection port during the measurement; the detection limit is $0.05 \mathrm{ppm}$ for hydrogen sulfide.

2.3. The CALPUFF Model. The CALPUFF model was approved by the US Environmental Protection Agency (EPA) as a useful tool to determine atmospheric dispersion, especially in areas with pollution sources such as landfills. It combines three major components: CALMET, CALPUFF, and CALPOST. A detailed description of the CALPUFF model could be found in a study by Scire et al. [17].

2.3.1. Meteorological Data. Due to the difficulty of the upper-air meteorological data acquisition in the selected area, the meteorological data simulated by the mesoscale meteorological model (MM5) were used as the initial guess wind field of the CALMET meteorological model.

The MM5 model's domains for the processing of the meteorological parameters in the study area consisted of a main domain (Domain 1) with a resolution of $1 \mathrm{~km}$ per point and a nested domain (Domain 2) with a resolution of $1 \mathrm{~km}$ per point. The integration step was $9 \mathrm{~s}$.

Using the MM5 as the initial guess wind field has been proven to be trustful in different research studies [18]. The validity of calculated meteorological data was verified by comparing them with the measured data from the meteorological station in the landfill (Figure 2).

2.3.2. Odor Threshold Regulations. The odor annoyance criterions of different countries are also rather diverse [19]. Mostly are based on the 98th percentile method proposed by the Lombardia region guidelines [20]. In odor diffusion modeling, very short averaging times (e.g., a few minutes) must be used [21]. Odors can be smelt intermittently for short periods. In the CALPUFF model, the averaged 1-h odor concentrations are converted to shorter averaging periods based on the power-law equation of the form:

$$
C_{s}=C_{h}\left(\frac{T_{h}}{T_{s}}\right)^{p},
$$

where $C_{s}$ is the required shorter time average concentration; $C_{h}$ is the hourly average concentration calculated by the CALPUFF model; $T_{h}$ is the 1 -h period expressed in minutes; $T_{s}$ is the short-term period in minutes; exponent $(\mathrm{p})$ : the CALPUFF manual advises the use of $1 / 5$ th power relationship. Nagata and Takeuchi showed that the olfactory 


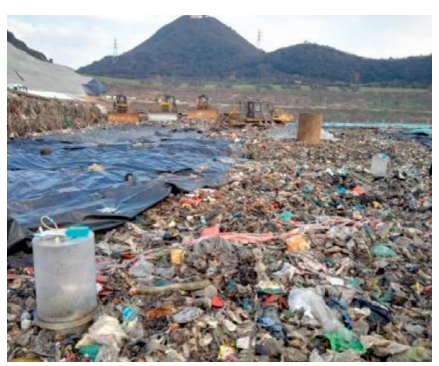

(a)

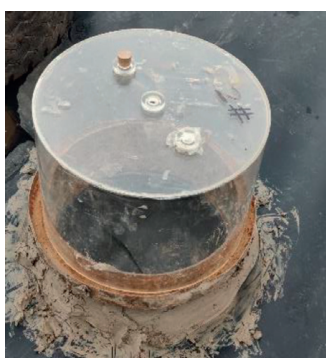

(b)

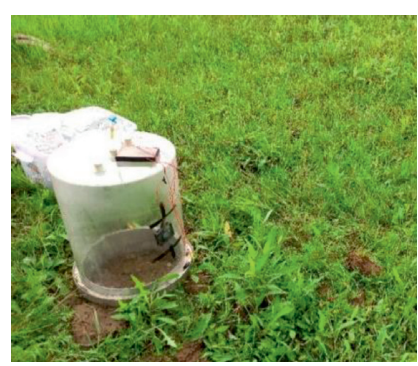

(c)

FIGURE 1: Gas sampling on the different areas of the landfill. (a) Working area. (b) Temporary cover area. (c) Final cover area.

threshold of $\mathrm{H}_{2} \mathrm{~S}$ was $0.41 \mathrm{ppb}\left(0.62 \mu \mathrm{g} / \mathrm{m}^{3}\right)$ [22]. Therefore, the $\mathrm{H}_{2} \mathrm{~S} 1$-h average limited concentration was $0.34 \mu \mathrm{g} / \mathrm{m}^{3}$.

2.4. Operation of CALPUFF. Figure 3 illustrates this study's diagram for CALPUFF operation. The spatial scale for analysis is $10 \mathrm{~km} \times 10 \mathrm{~km}$, and the mesh accuracy is $100 \mathrm{~m}$. The map used in this study was a Universal Transverse Mercator (UTM) Reference Ellipsoid WGS-84, Global Coverage, UTM Zone 11 with coordinates $30.38^{\circ} \mathrm{N}$ and $120.21^{\circ} \mathrm{E}$. The mesh used was $10 \mathrm{~km} \times 10 \mathrm{~km}$ and 11 vertical levels for meteorology. The topography and land use were defined using the preprocessors "Terrel" and "CTGPROC."

\section{Results and Discussion}

3.1. The Emission Rate of Odorous Gas. All dispersion models need reasonably accurate emission data to produce reliable results. The $\mathrm{H}_{2} \mathrm{~S}$ emission rate on the working surface and temporary area during the monitoring period is shown in Figure 4. It is estimated that $20 \%$ of the landfill gas released directly from the landfill working area [23]. For the monitoring of $\mathrm{H}_{2} \mathrm{~S}$ in this site, the statistical data shown in Figure 4(a) indicated that the $\mathrm{H}_{2} \mathrm{~S}$ flux rate varied from $0.003 \mathrm{mg} / \mathrm{m}^{2} / \mathrm{min}$ to $0.98 \mathrm{mg} / \mathrm{m}^{2} / \mathrm{min}$, equivalent to the annual $\mathrm{H}_{2} \mathrm{~S}$ emission varied between $1.57 \times 10^{4} \mathrm{~g} / \mathrm{a}$ and $515 \times 10^{4} \mathrm{~g} / \mathrm{a}$, which was comparable to the results measured in South Korean landfills $\left(0 \sim 13.6 \times 10^{4} \mathrm{~g} / \mathrm{a}\right)$ [24].

The arithmetic mean value of $\mathrm{H}_{2} \mathrm{~S}$ flux rate increased with the ambient temperature, reaching its peak value of $0.2502 \mathrm{mg} /$ $\mathrm{m}^{2} / \mathrm{min}$ in June 2017 . The maximum flux rate of $0.98 \mathrm{mg} / \mathrm{m}^{2}$ / min was also monitored at a single point in June 2017. This rule has also been verified by other scholars. Kim indicated that the flux of sulfur-contained organic compounds would peak in summer and changed with seasons [24]. Ji reported the $\mathrm{H}_{2} \mathrm{~S}$ concentration peaked between July and September, which caused by the higher water content of MSW in summer. The field monitoring results found that the variation tendency of $\mathrm{H}_{2} \mathrm{~S}$ flux was consistent with that of moisture content [25].

\subsection{The Analysis of the Critical Factors Affecting $\mathrm{H}_{2} \mathrm{~S}$ Diffusion.} Set a fixed point at the height of 10 meters, which was $1.7 \mathrm{~km}$ to the northwest from the landfill center to be analyzed. The initial ambient temperature was $21^{\circ} \mathrm{C}$, the ambient air pressure was $101.3 \mathrm{kPa}$, and the wind speed was $5.2 \mathrm{~m} / \mathrm{s}$.
Several factors that may influence the gas diffusion in the air were analyzed by the CALPUFF model.

3.2.1. Wind Velocity. The wind velocity degree was categorized by wind speed at 10 meters high off the open ground. The average wind speed varies with the altitude which is usually described by the logarithmic law or exponential law [26]. The regulation named "Load Code for the Design of Building Structure" (GB 50009-2001) adopts the exponential law [27]:

$$
\frac{V(z)}{V_{10}}=\left(\frac{z}{10}\right)^{\alpha},
$$

where $Z$ is the height to the ground; $\alpha$ is surface roughness; $V_{10}$ is the average wind velocity at 10 meters above the ground. The wind velocity at 10 meters above the ground was revised in accordance with the wind velocity level 1 7.

The variation of $\mathrm{H}_{2} \mathrm{~S}$ concentration with wind velocity is shown in Figure 5(a). Wind velocity played a very significant role in gas diffusion. The concentration appeared to significantly increase at initial and then decrease in the process of wind velocity variation from calm to level 3 .

3.2.2. Air Pressure. Considering the amplitude of the atmospheric pressure fluctuation [28], the pressure variation was set as $0, \pm 3 \mathrm{kPa}$, and $\pm 6 \mathrm{kPa}$. The variation of $\mathrm{H}_{2} \mathrm{~S}$ concentration with atmospheric pressure is shown in Figure 5(b). The result of the gas concentration at the fixed point indicated that amplitude of concentration change caused by the air pressure variation was $0.3 \%$. The pollutant concentration is negatively correlated with the increase in atmospheric pressure. The stronger turbulence caused by the higher atmospheric pressure will increase the regional wind speed and therefore reduce the pollutant concentration. Sadowska-Rociek et al. indicated that the variation of odorous gas concentration was directly related to air pressure [29]. The results of field monitoring showed that gas emission would increase during the low pressure in one day [30,31].

3.2.3. Air Temperature. The variation of air temperature would affect the $\mathrm{H}_{2} \mathrm{~S}$ migration rates directly. Set the air temperature to $0^{\circ} \mathrm{C}, 20^{\circ} \mathrm{C}$, and $35^{\circ} \mathrm{C}$; the variation of $\mathrm{H}_{2} \mathrm{~S}$ concentration with air temperature is shown in Figure 5(c). The results indicated that the $\mathrm{H}_{2} \mathrm{~S}$ concentration was changed positively with the air temperature variation, and the amplitude 


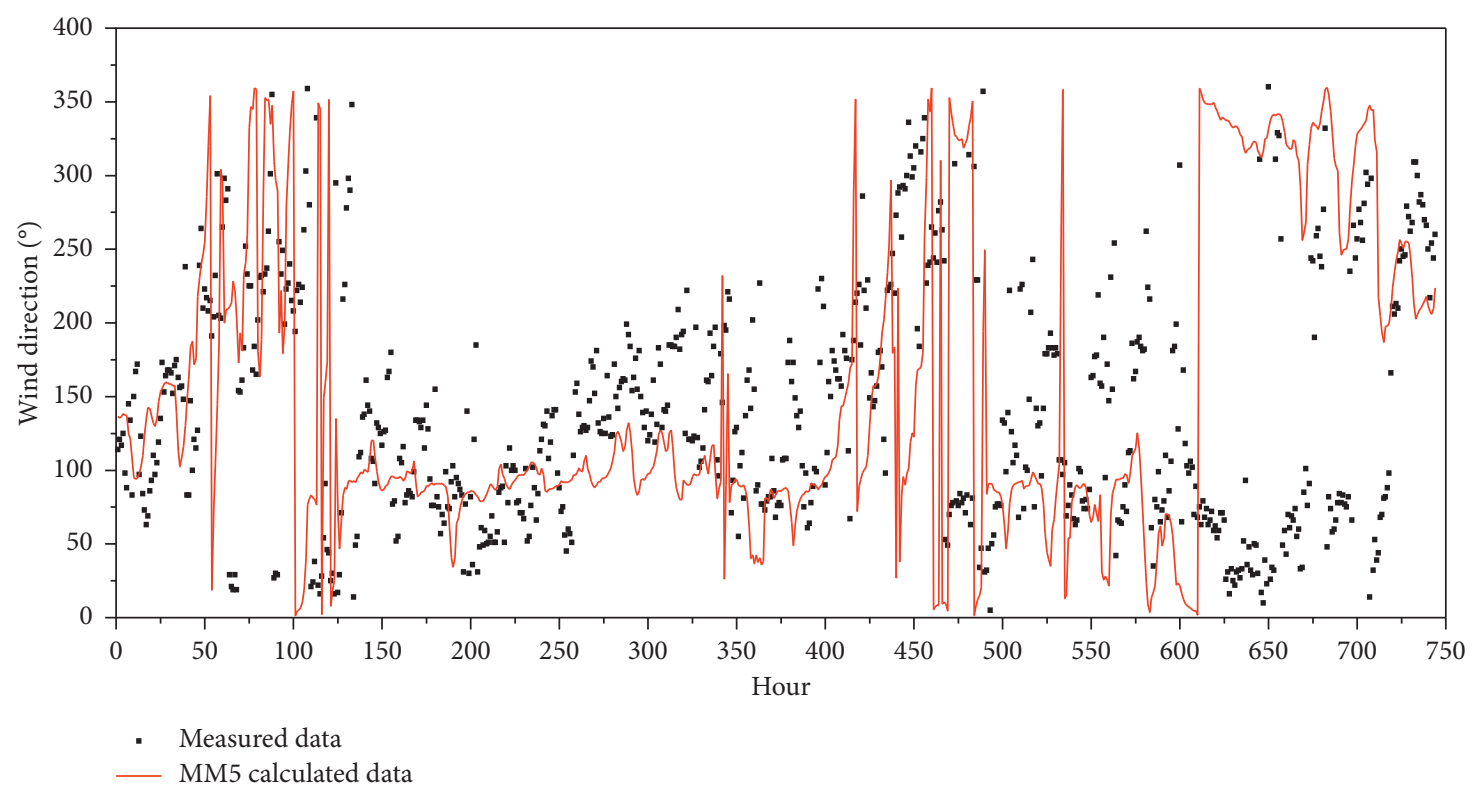

(a)

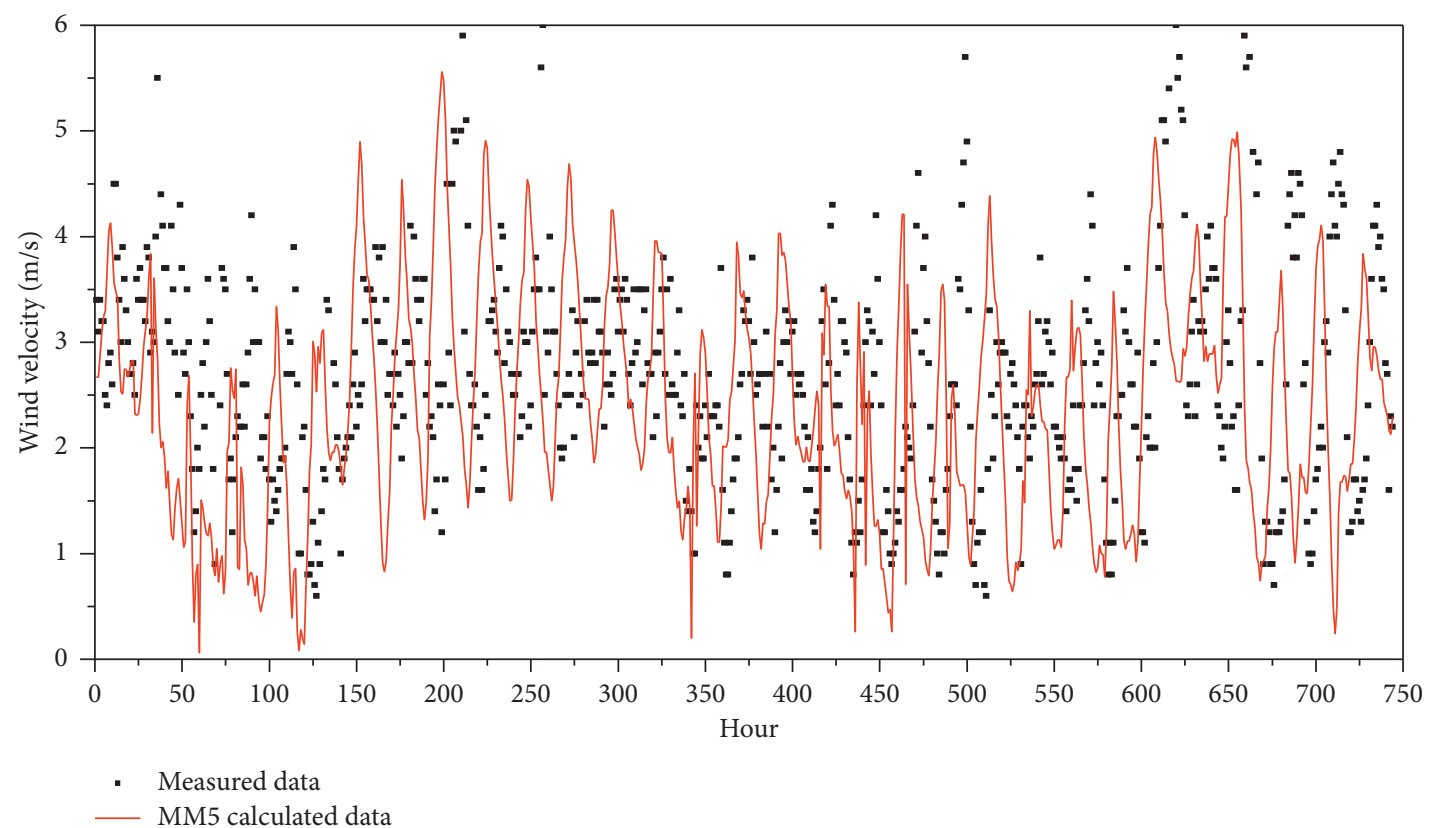

(b)

FIgURE 2: The comparison of measured and calculated meteorological data (Aug. 2016).

of concentration change was $0.6 \%$. The rise of temperature would reduce the atmospheric stability which may weaken the pollutant vertical convection in the air. Qiang et al. reported that the concentration of odorous gas in spring and summer was significantly higher than that in autumn and winter [32].

3.2.4. Emission Rates. The gas emission rate would be affected by several factors such as the composition, fill age, saturation, and mechanical movement of MSW. The measured $\mathrm{H}_{2} \mathrm{~S}$ emission rate is set to $F_{0}(0.125 \mathrm{~kg} / \mathrm{h})$; the variation of $\mathrm{H}_{2} \mathrm{~S}$ concentration with emission rate is shown in
Figure 5(d). The emission rate varied in the scope of $0.5 F_{0}$ to $1.5 F_{0}$, and the calculated results indicated that the $\mathrm{H}_{2} \mathrm{~S}$ concentration was linearly positively correlated with the variation of gas emission rate in the origin. The equation of the CALPUFF model also proved the linear positive correlation between the pollutant flux and concentration.

3.2.5. Surface Parameters. For the surface parameters of one landfill, the heat flux caused by human activity could be ignored; theoretical analysis and experiment proved that Bowen ratio and surface roughness are two sensitive 


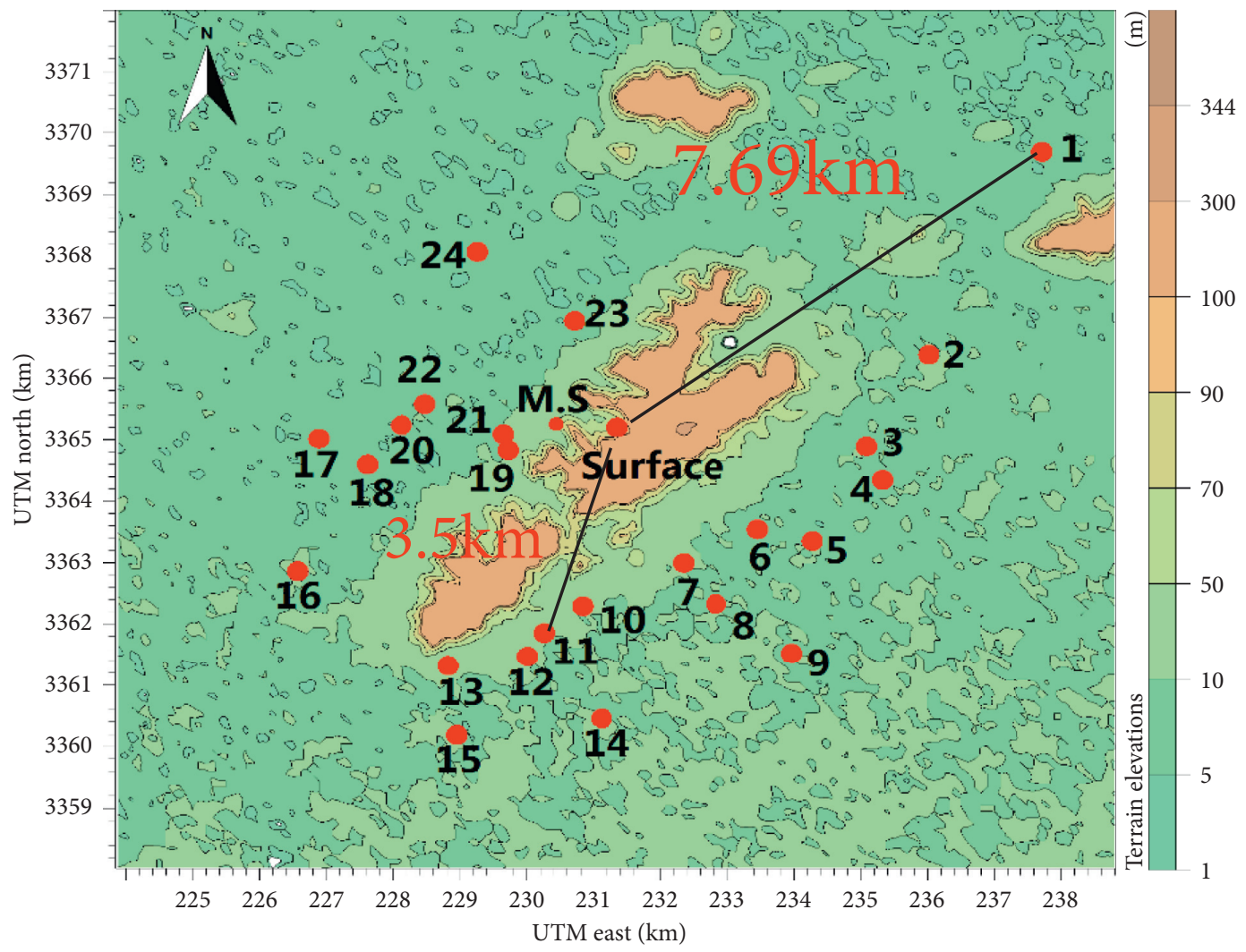

FIgURE 3: The distribution of the complained point (the numbers denote the different position; surface denotes the landfill working area and the origin of odor emission; MS denotes the meteorological station in the landfill).

parameters affecting surface gas concentration [33]. However, the geographical environment around the landfill site would keep constant. Therefore, the surface parameters would be regarded as constant values that would not be analyzed separately when analyzing the dynamic factors.

From the parametric analysis, it can be concluded that each parameter has a certain effect on the $\mathrm{H}_{2} \mathrm{~S}$ diffusion in the air; however, the influence of air temperature and air pressure could be ignored. The variation of gas emission rate was positively correlated with the change of gas concentration in fixed points. In addition, the variation of wind velocity was positively correlated with the $\mathrm{H}_{2} \mathrm{~S}$ concentration within a specific wind level range. This would imply that the high gas emission coupled with appropriate wind speed could cause a serious odorous problem in a certain range. Thus, it can be concluded that wind level and emission rate are the two key factors affecting $\mathrm{H}_{2} \mathrm{~S}$ diffusion in the air.

\subsection{Assessment of Odor Influence by CALPUFF. Massive} complaints against the odorous problems were investigated during 2016. The spatial distribution of complain points is shown in Figure 3. The complaints were concentrated in August, September, and October. No. 11 and no. 12 points occupied the major proportion of all the complaints, with 37 cases and 6 cases, respectively.

The no. 11 point was selected for further analysis. The detailed complaints which contain the specific date and time are listed in Table 1.
According to the 16-wind direction map, the no. 11 point was located $3.5 \mathrm{~km}$ south-southwest (SSW) to the landfill. The malodorous material released from the landfill could be directly blown to the no. 11 point when the wind direction was north-northeast (NNE), northeast (NE), and eastnortheast (ENE). The CALPUFF model was used to analyze the percentage of wind that blew directly to the no. 11 point; the results are shown in Table 2. The percentage of wind that blew directly to no. 11 reached $27.9 \%, 7.86 \%, 20.9 \%, 58.32 \%$, and $47.3 \%$, respectively, during the 5 periods with massive complaints. The frequency of wind direction was consistent with the complaint occurrence.

The $\mathrm{H}_{2} \mathrm{~S}$ flux at the working area was assumed to be kept constant at $0.125 \mathrm{~kg} / \mathrm{h}$. According to the $\mathrm{H}_{2} \mathrm{~S}$ distribution calculated by CALPUFF (Figure 6(a)), the area within $5 \mathrm{~km}$ of the landfill would be interfered by the odorous problem. The averaged $\mathrm{H}_{2} \mathrm{~S}$ concentration at the no. 11 point reached $9.1 \mu \mathrm{g} / \mathrm{m}^{3}$, which is 15 times greater than the olfactory threshold. Therefore, proper engineering measures such as controlling the exposed area or increasing the gas collection should be taken to ensure the emission rate of $\mathrm{H}_{2} \mathrm{~S}$ decreases to $15 \%$ of its original value. Cai et al. reviewed nine LFG mitigation measures, including refinement process for MSW landfilling (RPL), LFG collection and flaring (LCF), and LFG collection and power generation (LCP) and found that the implementation of these methods could lead to the malodorous emission reduction of $90 \sim 95 \%$ theoretically [34]. 


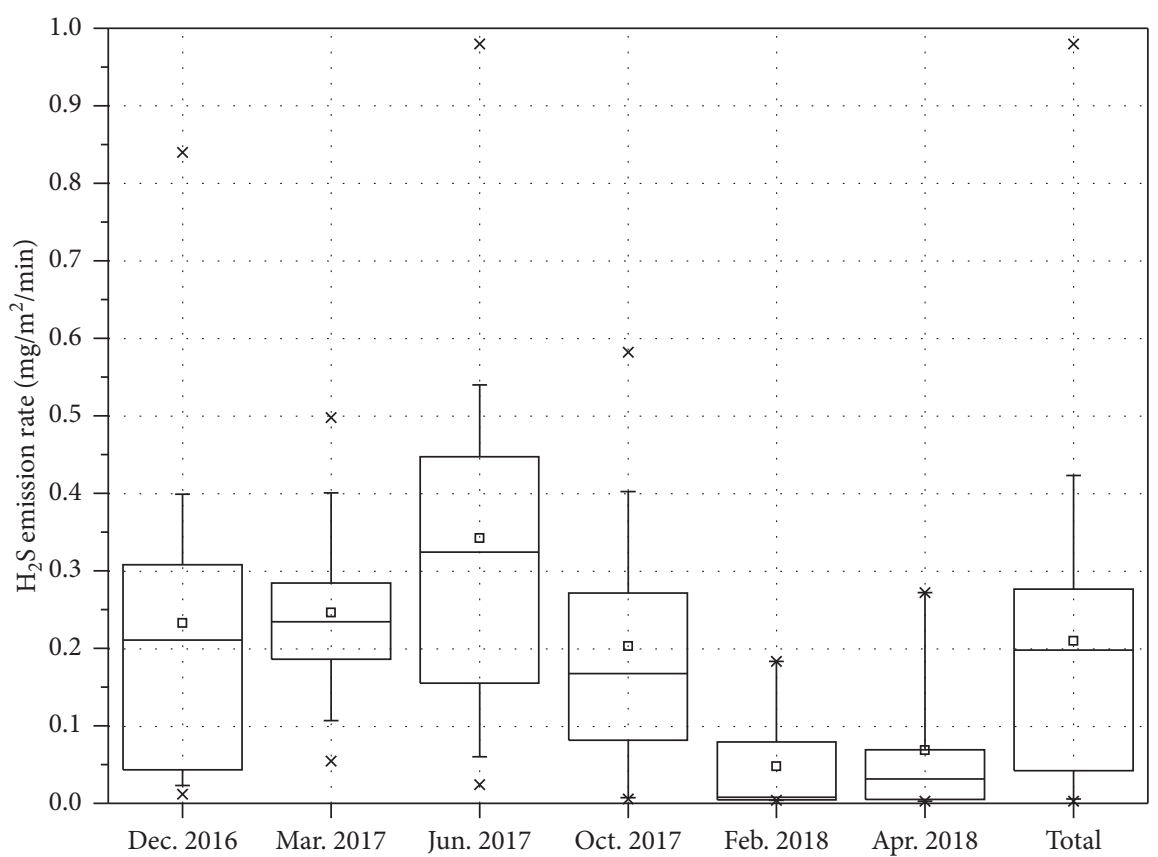

(a)

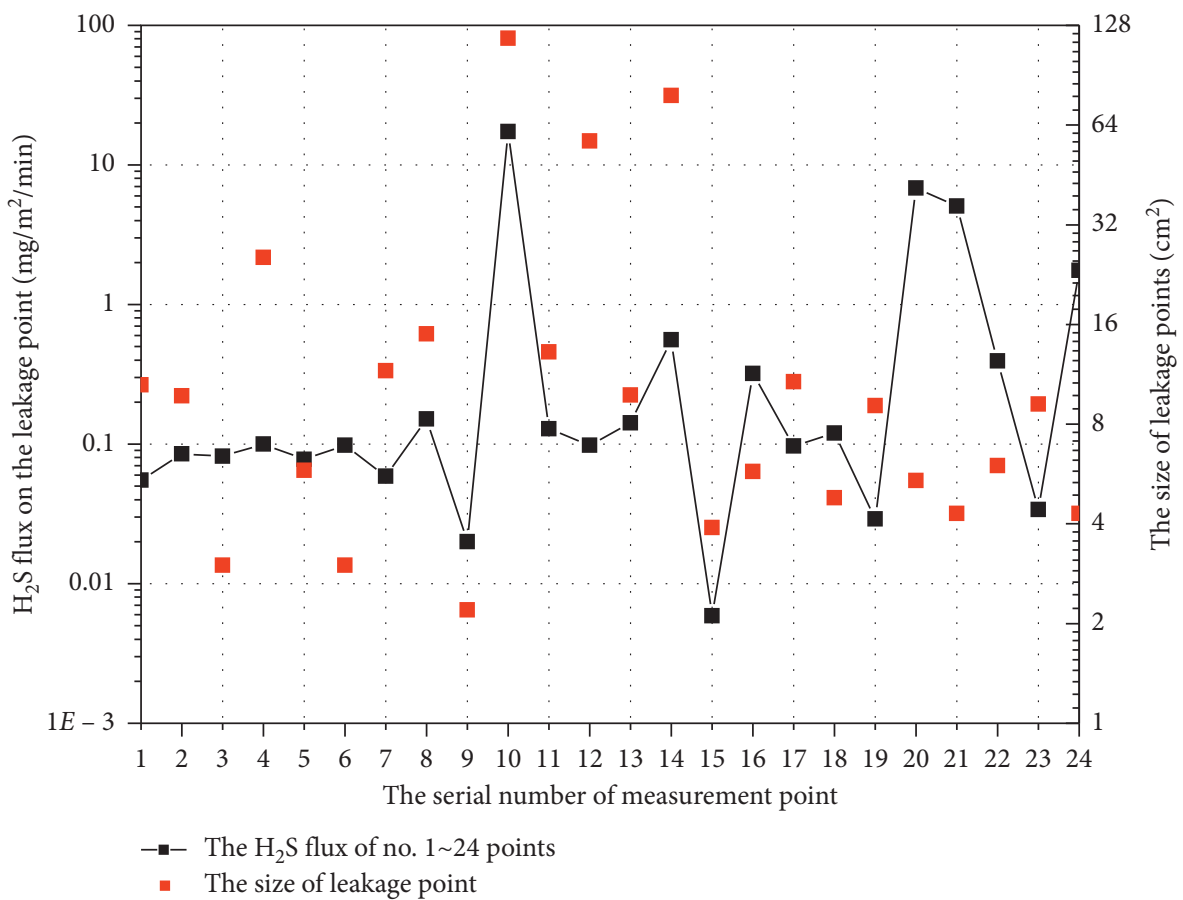

(b)

FiguRE 4: $\mathrm{H}_{2} \mathrm{~S}$ emission rates in different covers. (a) $\mathrm{H}_{2} \mathrm{~S}$ emission rates on the working area. (b) $\mathrm{H}_{2} \mathrm{~S}$ emission rates on the leakage points. 


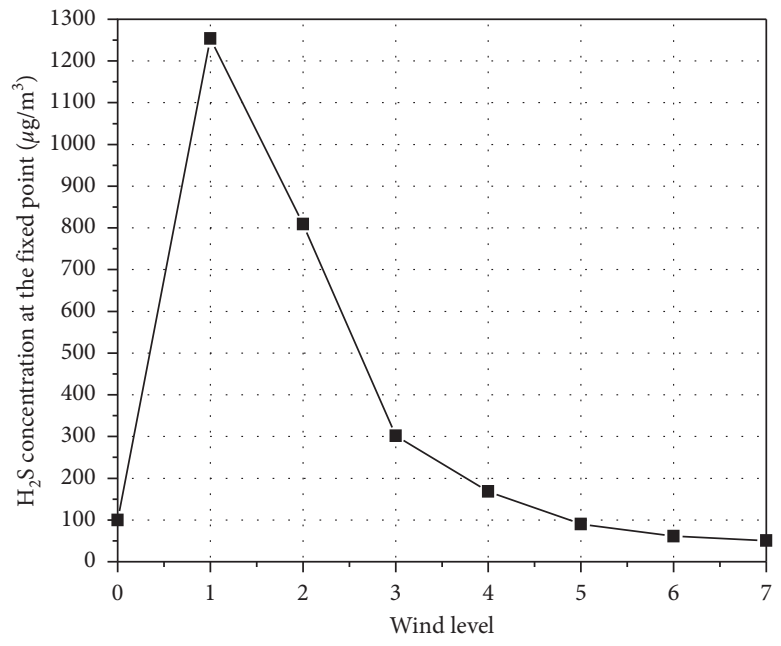

(a)

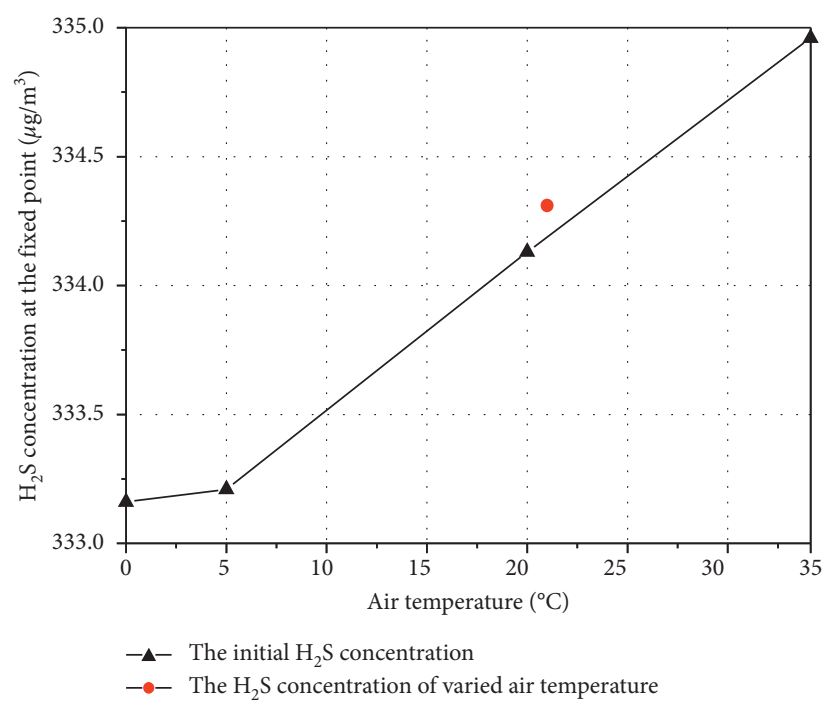

(c)

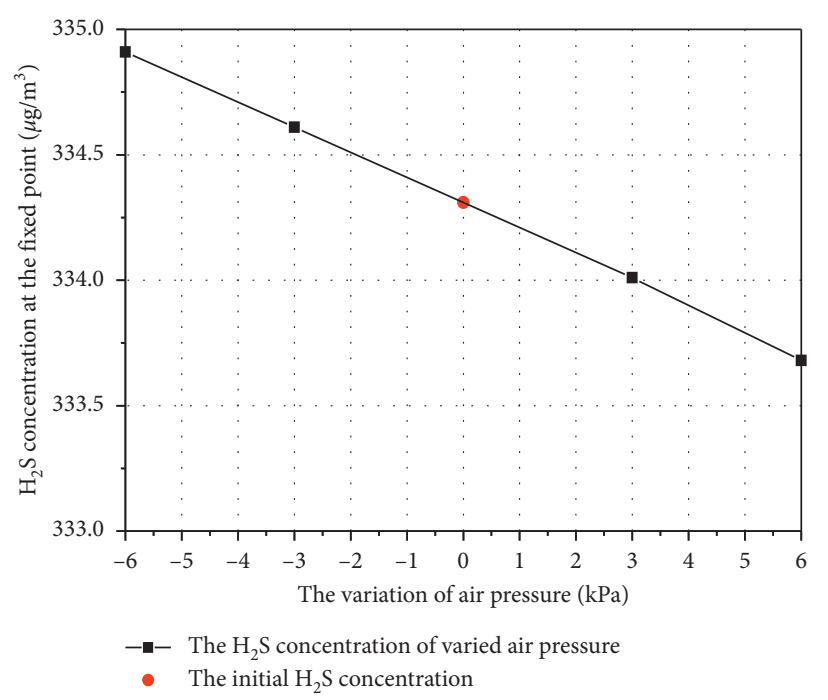

(b)

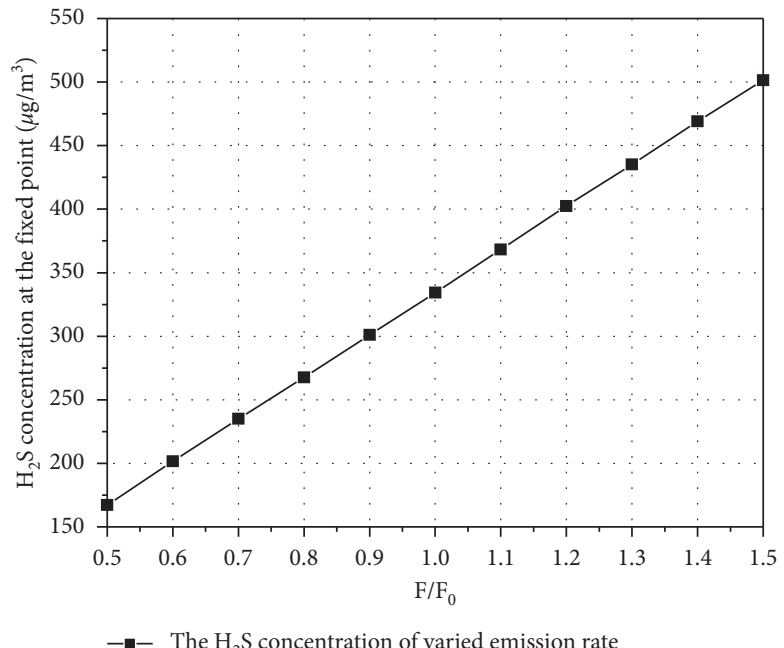

(d)

Figure 5: The varied $\mathrm{H}_{2} \mathrm{~S}$ concentration with different factors. (a) Wind level. (b) Air pressure. (c) Air temperature. (d) Emission rate.

TABLe 1: A detailed complain inventory of no. 11 in August, September, and October.

\begin{tabular}{|c|c|c|c|c|}
\hline Scenario & $\begin{array}{c}\text { Time of } \\
\text { complaint }\end{array}$ & The description of complaint & $\begin{array}{c}\text { Analysis } \\
\text { dates }\end{array}$ & $\begin{array}{c}\text { Analysis } \\
\text { periods }\end{array}$ \\
\hline 1 & $\begin{array}{l}8.17 \\
8.17\end{array}$ & $\begin{array}{l}\text { Odors from the Tianziling landfill occurred at 16:00 pm-8:00 am. } \\
\text { Odors from the Tianziling landfill occurred at about } 21: 00 \mathrm{pm} \text { in recent days. }\end{array}$ & $8.10 \sim 8.17$ & $16 \mathrm{pm} \sim 8 \mathrm{am}$ \\
\hline 2 & $\begin{array}{l}9.4 \\
9.6\end{array}$ & $\begin{array}{l}\text { Odors from the Tianziling landfill occurred from wee hours to } 8: 00 \mathrm{am} \text {. } \\
\text { Odors from the Tianziling landfill occurred at } 8: 00 \text { am every day during half a } \\
\text { year. }\end{array}$ & $9.1 \sim 9.6$ & $0 \sim 8$ am \\
\hline 3 & 9.7 & Odors from the Tianziling landfill occurred in a rainy day recently. & $9.6 \sim 9.7$ & Whole day \\
\hline 4 & $\begin{array}{l}10.13 \\
10.13 \\
10.13 \\
10.13 \\
10.15 \\
\end{array}$ & $\begin{array}{l}\text { Odors from the Tianziling landfill occurred at } 00: 49 \text { am in BanShan street and } \\
\text { Tianyuan community. } \\
\text { Odors from the Tianziling landfill occurred at } 0: 00 \text { am-1:00 am or } 5: 00 \text { am-6: } \\
\qquad 00 \text { am every day. } \\
\text { Odors from the Tianziling landfill occurred at } 20: 30 \mathrm{pm} \text { on } 12 / 10 / 2016 \text { and } \\
\text { complained by the residents of Tianyuan community. } \\
\text { Odors from the Tianziling landfill occurred in the afternoon on 10/10/2016. } \\
\text { Odors from the Tianziling landfill occurred at } 6: 00 \text { am-8:00 am and } 18: 00 \\
\text { pm-23:00 pm. The situation lasted for a year. } \\
\text { Odors from the Tianziling landfill occurred severely at } 18: 00 \text { pm-23:00 pm. } \\
\text { Odors from the Tianziling landfill occurred at } 8: 00 \text { pm on } 12 / 10 / 2016 \text {. }\end{array}$ & $10.10 \sim 10.13$ & $18 \mathrm{pm} \sim 8$ am \\
\hline
\end{tabular}


TABle 1: Continued.

\begin{tabular}{|c|c|c|c|c|}
\hline Scenario & $\begin{array}{l}\text { Time of } \\
\text { complaint }\end{array}$ & The description of complaint & $\begin{array}{l}\text { Analysis } \\
\text { dates }\end{array}$ & $\begin{array}{l}\text { Analysis } \\
\text { periods }\end{array}$ \\
\hline \multirow{4}{*}{5} & 10.22 & $\begin{array}{l}\text { Odors from the Tianziling landfill occurred at } 6: 00 \mathrm{am}, 8: 00 \mathrm{pm} \text {, or even at } \\
\text { midnight. }\end{array}$ & \multirow{4}{*}{$10.22 \sim 10.27$} & \multirow{4}{*}{$19 \mathrm{pm} \sim 7 \mathrm{am}$} \\
\hline & 10.23 & Odors from the Tianziling landfill occurred throughout the day irregularly. & & \\
\hline & 10.23 & $\begin{array}{c}\text { Odors from the Tianziling landfill occurred at } 22: 00 \mathrm{pm} \text { on } 10 / 23 / 2016 \text {, which } \\
\text { was severe since } 2016 .\end{array}$ & & \\
\hline & 10.27 & Odors from the Tianziling landfill occurred in the midnight recently. & & \\
\hline
\end{tabular}

TABLE 2: The percentage of the wind that directly blew to the no. 11 area in different scenarios.

\begin{tabular}{lc}
\hline The scenario number & The percentage of the wind that directly blew to the no. 11 area (\%) \\
\hline 1 & 7.86 \\
2 & 20.9 \\
3 & 58.32 \\
4 & 21.5 \\
5 & 47.3 \\
\hline
\end{tabular}

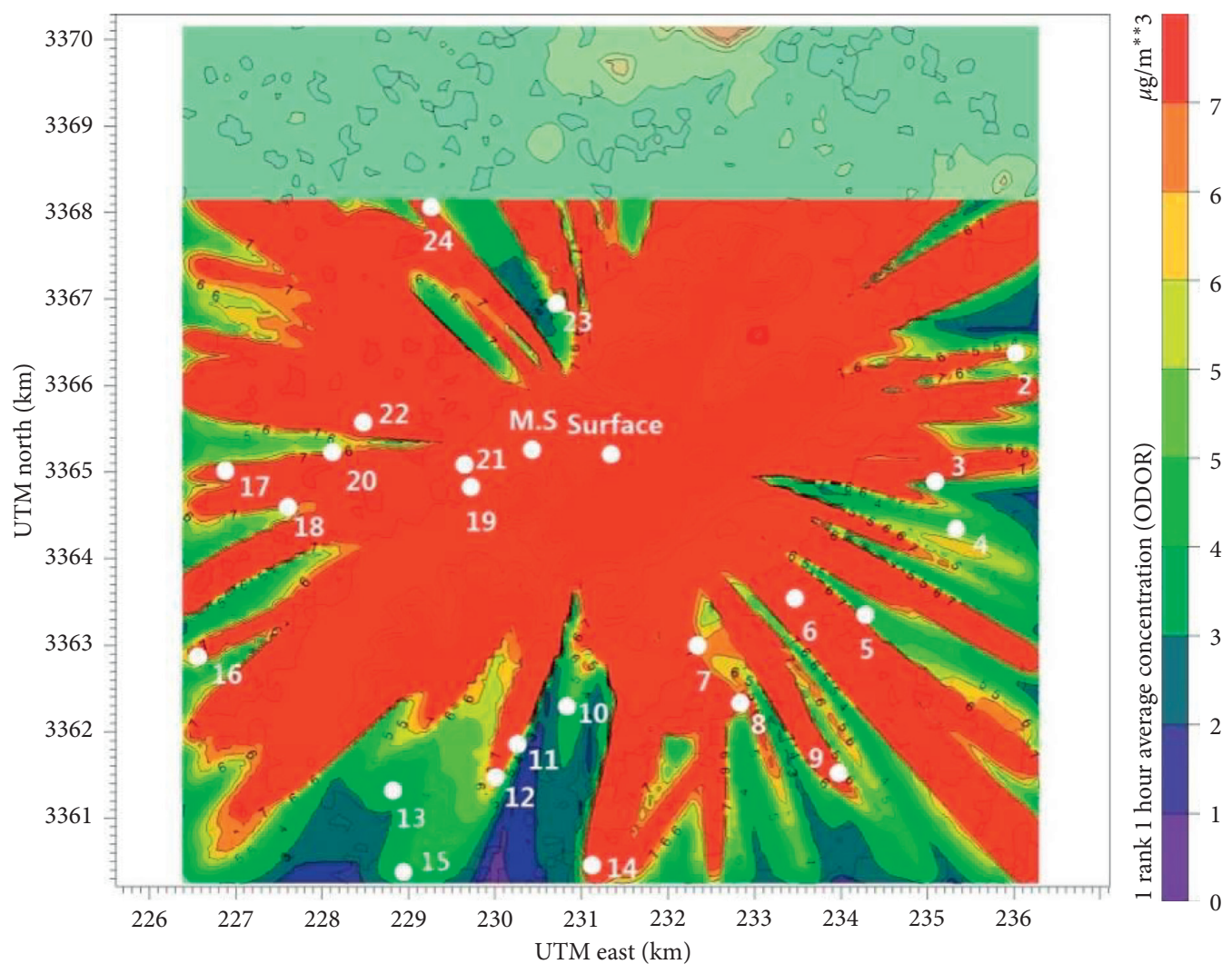

(a)

Figure 6: Continued. 


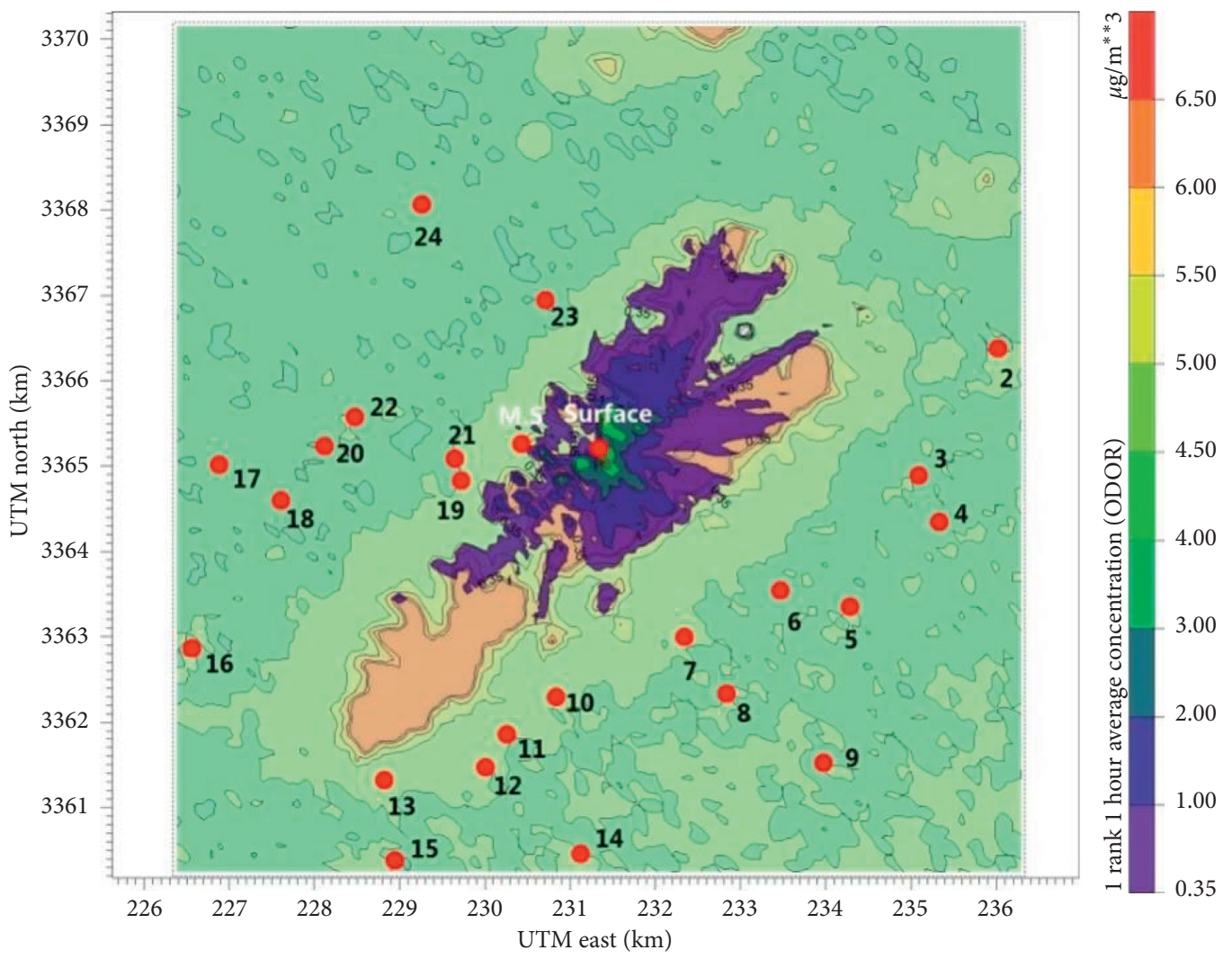

(b)

Figure 6: The comparison of $\mathrm{H}_{2} \mathrm{~S}$-influenced area sizes with different gas emission rates (surface denotes the landfill working area and the origin of odor emission; MS denotes the meteorological station in the landfill). (a) The $\mathrm{H}_{2} \mathrm{~S}$-influenced area with the original emission rate on the site $(0.125 \mathrm{~kg} / \mathrm{h})$. (b) The $\mathrm{H}_{2} \mathrm{~S}$-influenced area with the reduced emission rate on the site.

\section{Conclusions}

The odorous gas $\mathrm{H}_{2} \mathrm{~S}$ was monitored and analyzed in a large-scale landfill in Hangzhou, China. The CALPUFF model was adopted to evaluate the odor influence to the surrounding residential areas. The main conclusions are drawn as follows:

(1) The emission rate of $\mathrm{H}_{2} \mathrm{~S}$ varied from $0.003 \mathrm{mg} / \mathrm{m}^{2} / \mathrm{min}$ to $0.98 \mathrm{mg} / \mathrm{m}^{2} / \mathrm{min}$ on the working area of the landfill, and it was positively correlated with the ambient temperature. The emission of $\mathrm{H}_{2} \mathrm{~S}$ varied between $0.125 \mathrm{~kg} / \mathrm{h}$ and $1.09 \mathrm{~kg} / \mathrm{h}$ on the working area, and it varied between $9.2 \times 10^{-6} \mathrm{~kg} / \mathrm{h}$ and $6.8 \times 10^{-4} \mathrm{~kg} / \mathrm{h}$ on the temporary cover when considering the impact of the holes in the HDPE membrane, and it was negligible on the final cover. The contribution rates of $\mathrm{H}_{2} \mathrm{~S}$ emission in the whole landfill were 90.79\% 98.59\% and $0.0008 \% \sim 0.52 \%$ for the working area and the temporary cover area, respectively.

(2) The varied wind direction and speed are the key reasons of large-scale complaints against the odorous problems. The degree of coincidence between the point orientation and the wind direction reached $27.9 \%, 7.86 \%$, $20.9 \%, 58.32 \%, 21.5 \%$, and $47.3 \%$, respectively, during the six periods with high complaints occurrence. During that time, the prevailing wind speed varied from $1.6 \mathrm{~m} / \mathrm{s}$ to $3.3 \mathrm{~m} / \mathrm{s}$; the increasing of wind speed within this range would promote the higher $\mathrm{H}_{2} \mathrm{~S}$ concentration.

(3) Gas flux variation is another critical factor to affect the odor dispersion. Proper engineering measures should be taken to ensure the emission rate of $\mathrm{H}_{2} \mathrm{~S}$ lower than $15 \%$ of its original value, such as increasing the gas collection rate.

\section{Data Availability}

The data used to support the findings of this study are available from the corresponding author upon request

\section{Disclosure}

A part of the findings in this paper has been published in the Proceedings of 8th International Congress on Environmental Geotechnics (Volume 2).

\section{Conflicts of Interest}

The authors declare that they have no conflicts of interest regarding the publication of this paper. 


\section{Acknowledgments}

The authors are very grateful for the financial support of the National Natural Science Foundation of China (Grant nos. 51708508 and 51978625) and the Science Technology Department of Zhejiang Province (Grant no. 2019C03107).

\section{References}

[1] M. R. Allen, A. Braithwaite, and C. C. Hills, "Trace organic compounds in landfill gas at seven U.K. waste disposal sites," Environmental Science \& Technology, vol. 31, no. 4, pp. 1054-1061, 1997.

[2] L.-T. Zhan, H. Xu, Y.-M. Chen et al., "Biochemical, hydrological and mechanical behaviors of high food waste content MSW landfill: preliminary findings from a large-scale experiment," Waste Management, vol. 63, pp. 27-40, 2017.

[3] B. F. Staley, F. Xu, S. J. Cowie, M. A. Barlaz, and G. R. Hater, "Release of trace organic compounds during the decomposition of municipal solid waste components," Environmental Science \& Technology, vol. 40, no. 19, pp. 5984-5991, 2006.

[4] R. Chiriac, J. De Araujos Morais, J. Carre, R. Bayard, J. M. Chovelon, and R. Gourdon, "Study of the VOC emissions from a municipal solid waste storage pilot-scale cell: comparison with biogases from municipal waste landfill site," Waste Management, vol. 31, no. 11, pp. 2294-2301, 2011.

[5] S. L. Shen, Monitoring Method and Emission Mechanisms of Landfill Gas in Municipal Solid Waste Landfill, Zhejiang University, Hangzhou, China, 2020.

[6] P. Henshaw, J. Nicell, and A. Sikdar, "Parameters for the assessment of odour impacts on communities," Atmospheric Environment, vol. 40, no. 6, pp. 1016-1029, 2006.

[7] S. C. Zou, S. C. Lee, C. Y. Chan et al., "Characterization of ambient volatile organic compounds at a landfill site in Guangzhou, South China," Chemosphere, vol. 51, no. 9, pp. 1015-1022, 2003.

[8] J.-J. Fang, N. Yang, D.-Y. Cen, L.-M. Shao, and P.-J. He, “Odor compounds from different sources of landfill: characterization and source identification," Waste Management, vol. 32, no. 7, pp. 1401-1410, 2012.

[9] R. N. Gonzalez, E. Bjoerklund, R. Forteza, and V. Cerda, "Volatile organic compounds in landfill odorant emissions on the island of Mallorca," International Journal of Environmental Analytical Chemistry, vol. 93, no. 1-5, pp. 434-449, 2013.

[10] C. Chemel, C. Riesenmey, M. Batton-Hubert, and H. Vaillant, "Odour-impact assessment around a landfill site from weather-type classification, complaint inventory and numerical simulation," Journal of Environmental Management, vol. 93, no. 1, pp. 85-94, 2012.

[11] R. C. Brandt, H. A. Elliott, M. A. A. Adviento-Borbe, E. F. Wheeler, P. J. A. Kleinman, and D. B. Beegle, "Field olfactometry assessment of dairy manure land application methods," Journal of Environmental Quality, vol. 40, no. 2, pp. 431-437, 2011.

[12] L. Capelli, S. Sironi, R. Del Rosso, P. Céntola, A. Rossi, and C. Austeri, "Olfactometric approach for the evaluation of citizens' exposure to industrial emissions in the city of terni, Italy," Science of the Total Environment, vol. 409, no. 3, pp. 595-603, 2011.

[13] Ministry of Ecology and Environment of the People's Republic of China, Guidelines for Environmental Impact Assessment-Atmospheric Environment (HJ2.2-2008), China Environmental Science Press, Beijing, China, 2008.
[14] L. Capelli, S. Sironi, R. Del Rosso, and J.-M. Guillot, "Measuring odours in the environment vs. dispersion modelling: a review," Atmospheric Environment, vol. 79, pp. 731-743, 2013.

[15] S. Shen, Q. Wang, Y. Chen et al., "Effect of landfill odorous gas on surrounding environment: a field investigation and numerical analysis in a large-scale landfill in Hangzhou, China," in Proceedings of the 8th International Congress on Environmental Geotechnics Volume 2, pp. 51-59, Hangzhou, China, October 2019.

[16] D. G. M. Senevirathna, G. Achari, and J. P. A. Hettiaratchi, “A laboratory evaluation of errors associated with the determination of landfill gas emissions," Canadian Journal of Civil Engineering, vol. 33, no. 3, pp. 240-244, 2006.

[17] J. S. Scire, D. G. Strimaitis, and R. J. Yamartino, "A User's Guide for the CALPUFF Dispersion Model (Version 5)," Earth Tech Inc., Concord, MA, USA, 2000.

[18] X. W. Wang, Study on the Effect of Vehicle Exhaust on Visibility Based on Calpuff Model of Hangzhou, Zhejiang University, Hangzhou, China, 2013.

[19] T. Elbir, F. Dincer, and A. Muezzinoglu, "Evaluation of measured and predicted odor concentrations around a meat packaging and rendering plant," Environmental Engineering Science, vol. 24, no. 3, pp. 313-320, 2007.

[20] S. Sironi, L. Capelli, P. Céntola, R. Del Rosso, and S. Pierucci, "Odour impact assessment by means of dynamic olfactometry, dispersion modelling and social participation," Atmospheric Environment, vol. 44, no. 3, pp. 354-360, 2010.

[21] P. Mussio, A. W. Gnyp, and P. F. Henshaw, "A fluctuating plume dispersion model for the prediction of odour-impact frequencies from continuous stationary sources," Atmospheric Environment, vol. 35, no. 16, pp. 2955-2962, 200.

[22] Y. Nagata and N. Takeuchi, "Measurement of odor threshold by triangle odor bag method," Odor Measurement Review, vol. 118, pp. 118-127, 2003.

[23] K. Spokas, J. Bogner, J. P. Chanton et al., "Methane mass balance at three landfill sites: what is the efficiency of capture by gas collection systems?," Waste Management, vol. 26, no. 5, pp. 516-525, 2006.

[24] K.-H. Kim, "Emissions of reduced sulfur compounds (RSC) as a landfill gas (LFG): a comparative study of young and old landfill facilities," Atmospheric Environment, vol. 40, no. 34, pp. 6567-6578, 2006.

[25] H. Ji, Malodor Producing Mechanism and the Study on its Dynamic Changes in Landfill, China Agricultural University, Beijing, China, 2004.

[26] B. Zhu, Studies on Wind-Induced Dynamic Response and Vibration Control of Guyed Cat-Head Transmission TowerLine System, Soochow University, Suzhou, China, 2011.

[27] Ministry of Housing and Urban Rural Development of the People's Republic of China, Load Code for the Design of Building Structures (GB 50009-2001), China Architecture \& Building Press, Beijing, China, 2001.

[28] F. He, Subsurface Airflow Induced by Atmospheric Pressure Fluctuation, Liaoning Normal University, Dalian, China, 2009.

[29] A. Sadowska-Rociek, M. Kurdziel, E. Szczepaniec-Cięciak et al., "Analysis of odorous compounds at municipal landfill sites," Waste Management \& Research, vol. 27, no. 10, pp. 966-975, 2009.

[30] J. Gebert and A. Groengroeft, "Passive landfill gas emission-influence of atmospheric pressure and implications for the operation of methane-oxidising biofilters," Waste Management, vol. 26, no. 3, pp. 245-251, 2006. 
[31] J. Einola, K. Sormunen, A. Lensu, A. Leiskallio, M. Ettala, and J. Rintala, "Methane oxidation at a surface-sealed boreal landfill," Waste Management, vol. 29, no. 7, pp. 2105-2120, 2009.

[32] N. Qiang, H. Y. Wang, A. H. Zhao, W. X. Yuan, and M. Chen, "Odor emission rate of municipal solid waste from landfill working area," Huanjing Kexue, vol. 35, no. 2, pp. 513-519, 2014.

[33] H. Zhu, X. H. Cai, H. S. Zhang, L. Kang, and J. Y. Chen, "Atmospheric dispersion simulation in low wind conditions in inland hills and valleys," Acta Scientiae Circumstantiae, vol. 31, no. 3, pp. 613-623, 2011.

[34] B. F. Cai, Z. Y. Lou, J. N. Wang et al., " $\mathrm{CH}_{4}$ mitigation potentials from China landfills and related environmental cobenefits," Science Advances, vol. 4, no. 7, Article ID eaar8400, 2018. 